\title{
Religious Tourism Development in Ethiopia: Challenges and Opportunities at Adyame Yordanos Wonkshet St. Gabriel Monastery
}

\author{
Dagnachew Nega Daricha ${ }^{1 *}$ Engdu Gebrewold Weldesenbet ${ }^{2}$ \\ 1 Lecturer, Department of Tourism \& Hotel Management, Debre Tabor University, Ethiopia \\ 2 Assistant Professor, Department of Tourism Management, University of Gondar, Ethiopia
}

\begin{abstract}
Religious tourism is one of the fastest growing types of tourism in the world where many religious sites are endowed with lots of potentials for helping the religious tourism development and Ethiopia is one of them. Though the country is the home of religious potentials, its challenges and opportunities have not been fully unexploited as yet. Thus, this study stands with the aim of assessing the challenges and opportunities for religious tourism development in the case of Adyame Yordanos Wonkshet Monastery, Ethiopia. For this study, qualitative research approach was followed to collect data and descriptive design was employed. The target populations were the tourism experts in the zone and district, South Gondar Zone diocese, Aferwanat diocese leaders, the monastery leaders and monks. 25 respondents were selected through purposive sampling. Primary sources were gathered from interview, focus group discussion \& field observation and secondary source were from different documents thereby thematic analysis was undertaken. Findings indicated that the challenges explored at the monastery include thefts and robbery, insufficient land, lack of infrastructure, parking problem, loss of spirituality, unskilled experts and unity and coordination problems. Opportunities include the growing number of religious tourists, technological advancement, cured religious tourists from their mental and physical illness, the Blue Nile Fall \& Blue Nile Camp and Government policy. Therefore, the tourism stakeholders should be integrated together to use potentials; solve challenges through examining opportunities for ensuring religious tourism development in the monastery.
\end{abstract}

Key words: challenge, opportunity, religions tourism, monastery

DOI: $10.7176 / \mathrm{JTHS} / 40-02$

\section{Introduction}

Currently, tourism is found among the leading and promising sectors of the world (Nurhssen, 2016; Gurung, 2016). Since the $19^{\text {th }}$ century, tourism has increasingly played a significant role for lots of rich and developing countries .moreover; it is true in the case of under developed countries as it is expanding rapidly in less the poor nations (UNWTO, 2005). Tourism as a huge sector has become one of the speedily prosperous economic sector in the world, and its earliest form is religion tourism that starts from the dawn of humanity (Farhat, Ummara \& Sundas, 2016).

Travel for religious reasons dates back to the Roman, Greek, Egyptian and Indus Valley civilizations, and is maybe the oldest and most prevalent type of travel in human history (TN Global Travel Industry News, 2014; Jackowski and Smith, 1992; as cited in Rodriques, 2012. Religion and tourism are always complementary with one another and are closely associated (O'Gorman, 2010; Destination BC corp., 2014). Okonkwo (2015) stated that religious tourism is one of the earliest forms of tourism that was practiced by people travelling to holy sites. This form of tourism could be traced way back to the dawn of humanity. Many people's already travelled for religious reasons in ancient Greece or pre-Christian times but religious tourism has become popular in the middle ages, when people started looking for salvation, they visited holy places. Later as they had more free time and during the period of the grand tours they started travelling more and more, also for leisure (Pintér, 2014). And today, millions of people travel throughout the world in search of sacredness, spiritual guidance, reaching places considered holy and worshipped (Tala, 2014).

The religious tourism is one of the fastest growing tourism products since 2007 (UNWTO, 2014). It is known that all over the world for its religious significance, the destination attracts approximately 18-20 million visitors domestic and international per annum, daily around 40,000 to 50,000 tourist to religious site (Petal, 2010; as cited in Melese, (2015). According to estimates by the World Tourism Organization, 300 - 330 million tourists visit the most important religious monuments in the world every year. Around 600 million national and 
international religious trips made globally. These are particularly important trips, as not only contribute to the economic development of a place but also mutual understanding and respect between different cultures (UNWTO, 2014).

The potential for tourism development in sub-Saharan Africa is noteworthy. The region has rich resources, with widespread natural and cultural attractions, and adventure opportunities (World Bank, 2013). As noted through Nurhssen (2016), Ethiopia has a unique feature of land in terms of natural, cultural, historical, and religious tourism assets and unique biodiversity and it has a big potential for tourism. It is an ancient country with complex historical fissures along religious lines. Ethiopia is the home to multitude of ethnicities, religions and cultures (Karbo, 2013).

Ethiopia is known as the home of the two major religions: Christianity and Islamic .Christians' religious tourism constitutes the biggest share of domestic tourism in the country. Travel for annual Saints festival and for passing fasting seasons while praying in monasteries are the most common practices of the religion followers (Ermias and Mulugeta, 2014).

Famous religious sites in Ethiopia have been mostly visited and well promoted for their historical and archaeological value than for their religious importance; for instance, Axum and Lalibela. Only religious festivals such as the True Cross and Epiphany are being promoted for their religious tourism importance. However Ethiopia's religious tourism potential is not well studied and it has not yet gained much attention by either the government or the people (Ermias \& Mulugeta, 2014).

South Gondar Zone is the place with lots of natural and cultural tourism heritages which can draw many of the domestic and foreign tourists from different corners of the world. There are a lots of tourism types which provide many benefits to the local communities, regions and to the country as a whole. For instance in the South Gondar Zone, the nature based tourism like Guna mountain, water tourism like parts of lake Tana, health and spa tourism in Wanzaye Spring Water, cultural tourism like Gafat Industrial Village, Betelihem Church, Wukro Medihanlealm Rock Hewon Church, Tana Chirkos Monastery, Adyame Yordanos Wonkshet Monastery (AYWM) are some of the potentials tourism resources which should get appropriate attentions (Hagerie Media \& SGZCTO, 2015). AYWM is one of the popular religious destinations in South Gondar Zone. Tourism in this monastery offers wide products to be seen (ibid).

Previous researches have not been under taken regarding the challenges and opportunities of the monastery for religious tourism development. As a result, unless these have been examined through the right stakeholders on the right time with appropriate measures, ensuring religious tourism development on the site will remain a dream. Thus, the researchers were eager to conduct a research on the challenges and opportunity of religious tourism development in the study area.

\section{Objectives of the study}

The objective of the research are to

$>$ Assess the challenges for religious tourism development in the case of Adyame Yordanos Wonkshet Monastery, Ethiopia.

$>$ Appraise the opportunities for religious tourism development in the case of Adyame Yordanos Wonkshet Monastery, Ethiopia.

\section{Research Methods}

Descriptive type of research through cross sectional research design was adopted to provide answers to the questions of this particular research problem at the monastery. The study espoused with qualitative approach which helps to find out the uniqueness of each particular situation by explanation and understanding the situation specific phenomenon through naturalistic, qualitative inquiry since tourism thrives on novelty and uniqueness, a religious tourism destination must maintain its uniqueness.

The target populations in the study were the religious leaders and monks in the monastery, South Gondar Zone and Dera district tourism experts, Aferwanat dioceses leaders, and South Gondar diocese leaders. Since information can be found on the hands of few people, a non-probability sampling technique and purposive in specific was used, where there is no attempt to create a sample that is statistically representative of a 
population. Rather, people or cases are chosen 'with purpose' to enable the researchers to explore the research questions. The cases are selected on the basis of characteristics or experiences that are directly related to the researchers' area of interest and the research questions, and will allow the researchers to study the research topic in-depth (Matthews \& Ross, 2010). Thus, eight informants from the monastery, nine informants from the South Gondar diocese, seven tourism experts (two from the Dera Culture and Tourism office and five from the zonal tourism experts) and one from the Aferwanat dioceses. Totally, 25 informants were selected purposively based on their experience, interest, proximity, knowledge, duties and responsibilities in the monastery. The numbers of respondents was determined based on the level of data saturation.

For the purpose of this research, to achieve the objectives, primary data was collected by using techniques like interviews, focus group discussion, field observation and photograph. Whereas, secondary data referred to documents such as books, magazines, research reports, journal article etc. Thus, in this study in-depth interview, filed observation, focus group discussion, books, magazines, research reports, articles were used based on their level of usage.

Data Analysis was accomplished by looking for key terms and phrases, the transcripts of key-informant interviews, were reduced to manageable blocks of text, from which relevant quotes have been selected (Stemler, 2001).Therefore, thematic analysis has been undertaken for this particular study. Before the actual analysis of the data, the collected data was sorted and categorized in accordance to its source and type. Data obtained through observation has been described in text with the support of pictures. Data obtained through interview with different key informants has been analyzed thematically.

\title{
Result and Findings
}

\section{Challenges for Religious Tourism Development}

Though the monastery is endowed with lots of religious potentials which are significant for the developments of the religious tourism at the monastery, it has complicated and diversified challenges which hinder the development of religious tourism. So these challenges have been identified through in-depth interview, FGD and field observation. Taking and examining the challenges will give a lesson for future religious tourism development at the monastery. Here below the challenges which have been encountered from different angles were themed and discussed as follows accordingly.

\section{A. Loss of Spirituality}

As the monastery is one of the religious sites, loss of spirituality for the religious tourists' side is trying to put its effect both in directly and indirectly on the religious tourism development. As Informants participated in this study during the interview and FGD session told researchers that today one of the most critical challenges which resulted through globalization is Loss of spirituality. In the earlier time, in Ethiopia, people highly believed in their God and have tried to pass most of their time in their nearest churches/ monasteries.

As assured from the FGD session, one can see how much the globalization is becoming the challenge for the religious tourism development. The impact is high during the annual celebration. Many religious tourists are not acting as they are at the religious sites. The violate most of the codes of conducts. Some are coming with technological products which can decrease the spiritual value of the place.

it as:

When interviewed, the tourism expert, about challenges faced from globalization the informant realized

\begin{abstract}
"I usually attend annual celebration of the monastery. Though the growing number of tourist to the site is applicable, they are violating the sites religious codes. It should be respected. It is the place where one can listen to the Holy Sprite. It the house of God. However, some of religious tourists are not considering this issue. The reason for this is modernization and the ways of life is highly affected through globalization. It finally leads us to loss of spirituality and being carelessness to our religious assets."
\end{abstract}

In addition to loss of spirituality, still commodification is another challenge. During the annual festival, since more than 30,000 religious tourists are coming to the monastery, many merchants are travelling with product and selling lots of religion related products; which are directly attached to the modern things than what the religion requires to getting money. They not only influence the management of religious sites and attractions 
through marketing and commodification, but also the maintenance and interpretation policies. Some religious heritage site custodians accept government funds to cover operational expenses and support conservation. However, accepting government money means that concessions will have to be made in terms of interpretation and the operation of tourism at the site (Olsen, 2006).

\section{B. Infrastructure Problem}

Observation clearly showed that, though the monastery is one of the famous religious tourism destinations, there is lack of standard accessibility to the monastery. As explained through the tourism expert at the zone level, there are three basic elements in the tourism industry. These are attractions, accommodation and accessibility. All the three elements should exist to enhance religious tourism development. Howe ever, there are critical challenges at the monastery regarding accessibility.

Observation and interview indicated that, to reach the monastery, religious tourist should pass either on the side of Anbesame town or through Tis Abay village travelling through the challenging roads and hard journey which take much time, and physical strain. The public transportation is not accessible. This indicates that religious tourists may not be interested to explore such tourist site due to the lack of good road connectivity.

Visitors must feel assured that they can access the sites they have come, often from very far, to see, without difficulty or delay (Bader, 2012). However, some argued that this route is the very interesting route on which the religious tourist can experience adventurous activities on their way to the monastery. There is an attractive view up to the actual compound of the monastery. However, this experience is limited to only to the young religious tourists since the road it not accessible to child religious tourists and for the elderly aged 50 and above and for patients also. The findings of Belay, in 2013, also assured lack of transportation as one of the biggest challenges for religious tourism development at the religious site in Ethiopia.

Currently, electric power is also one of the most critical problem for religious tourism development at the monastery. There are lots of religious activities which are held during the day. However it cannot be run as per its plan due to lack of the electric power.

Generally, FGD, interview and observation assured that the absence of electricity is a big problem in the monastery. Religious festivals, religious related practices can be highly facilitated with electric power. Most agreed that the main body in charge of providing electricity, here, is the government. Findings of a study in Gishen Debre Kerbe by Mr. Ermias Kifle and Dr. Mulugeta Fesha, in 2013, has also supported that lack of electricity, and lack of transportation access as the major challenges at many religious site in Ethiopia.

\section{Lack of Unity and Coordination}

As most interviewee agreed, there is no coordination among the monastery leaders, the local communities, the woreda and zone tourism experts, the local woreda and zone administrative bodies, and the south Gondar diocese due to conflict of interest and fair distribution of resources. Most informants agreed that though the monastery is interesting in its potentials, stakeholders are not working cooperatively. Though it is a very invaluable finding of the reestablishments of the monastery after 500 years back, there are many people and groups who are standing to eradicate the monastery again. One of the interviews stated that those who are standing as enemies of the monastery should carefully understand the value and services of the monastery; which it is providing for the religious tourists, for the communities, for pilgrimage, for the region and for the nation. following:

For the lack of unity and coordination among stakeholders in the monastery, an informant stated the
"We have big responsibilities to solve problems which are seen in the monastery by discussion. The Monastery is now being re-established after 500 years. There are many evidences in the place for being the ancient religious site. So we all should be delighted by its reestablishment. It clearly showed that God is always with Ethiopians. It is our asset. There may be challenges regarding the monastery. No one can solve our problems. We will solve it peacefully..."

The sayings of the interviewee shows, that, though there are problems in the monastery, it is a little bit difficult to solve. The religious people, the monastery and tourism stakeholders should be integrated to enhance religious tourism development in the monastery. Specific views of tourism determine whether or not care takers of religious heritage sites will cooperate with outside stakeholders. For example, if the religious authorities who operate the site view tourism in a negative way, tourism may be restricted. In addition to religious authorities, 
other important stakeholders include government organizations, urban planners, local and regional tourism managers, regional economic development agencies, and state-sponsored historical societies (Olsen, 2006). Simone-Charteris and W. Boyd studied the development of religious heritage tourism in Northern Ireland in 2010 and their result showed that lack of cooperation, and recommended collaboration and among stakeholders.

\section{Awareness Problem}

The monastery is one of the ancient religious sites and was reestablished in the near past. As it is reestablished after 500 years of its demolishing, working on the awareness and promotion on the tourism regard through the right professional is the critical solution. The numbers of religious tourists are rising with alarming rate from time to time. Most religious tourist are those who have been cured from their disease through the holy water; some of the religious tourist are those who are interested to watch the healing ceremony; others are still who are attending the activities of the monastery through its web sites www.wonkishet.com. Some of the tourists are like for the academician and researchers purpose; however still most of the informants agreed that as it is the home of lots of ancient potentials in its destination, using it for tourism development due to the lack of awareness can be one of the challenges for religious tourism development in the area. Religious tourism requires that more adequate studies be carried out in order to gain a better grasp of its dimension, forms, management and impacts on monuments, sites and territories (UNWTO, 2007). Similarly, the findings of Belay, in his study of religious tourism development at Gishen in 2013, the awareness problem is one of the most critical issues and challenges for religious sites.

\section{E. Unskilled Professional}

Most of the informants, employees in the tourism sector, clearly agreed that there is lack of tourism professional in the sector. The informants asserted that there is need for skilled manpower to utilize the potentials resource the site is endowed with, to tap the opportunities, allocate financial power, to attain vision, to achieve the long and short plan drafted. Lack of skilled man power is making our effort a zero sum game.

This study findings are in line with the findings of Kinfe Abrha. Knife, in his study of religious tourism development in Aksum in 2015, indicated that, lack of educated manpower in the tourism sector is one of the challenges of religious tourism development.

\section{F. Poor Parking Facility}

One of the tourist facilities in which the tourists need from the service provider is parking. To deliver quality service and make the tourists delighted; parking should exist in the tourist destination site. As the religious tourism destination, the monastery has no proper parking area. Currently, religious tourists have two options for parking their transportation medium in the two paths. The first parking option is found at Tis Abay village, $30 \mathrm{Km}$ from the city of Bahirdar. Here in the village, even there is no standard bus station. Thus, religious tourists are exposed for unnecessary expense which is still another main problem. The second option is in the hilly side nearby Atised Maryam monastery. It is a way through Hamusit town.

As most of the interviewees of the monastery leaders agreed, it is not recommended to park at the compound of the monastery. However, still no option is found to develop a standard place for parking purpose during the festivities. And for now, the monastery has assigned security guards who keep the cars from theft. Adequate parking problem is also found as the main challenges of the monastery in the study of Bader on the study of current situation, future developments and prospects of Islamic and Christian holy sites in Jordan conducted in 2012.

\section{G. Theft and Robbery}

Mengistu (2008), clearly stated that most of the time the crosses, the old books, manuscripts, and other religious products are the major focus of the theft. Their price is very high as the ancient religious products were produced from gold, silver and other expensive materials. Observation from the study area proved that, in addition to religious objects, during the peak season, the tourist belongings are the targets. It is not only religious tourists who are going to the monastery but also the thieves. Thieves purposively travel for such evil activities. Some religious tourists are coming with some expensive products like laptop, smart phone, video and photo cameras and the like. So such technological instruments are the target of the thieves.

At the monastery, religious tourists travelling through Tis Abay village are the easy targets of the thieves as they travel on foot. Here, most of the time, tourists who are travelling alone are vulnerable. Taking this challenge into consideration the monastery has tried to create strategies to minimize the effect. It has arranged 
security guards who are working in shifts. At least 8 security guards are assigned to work in a single day. Here religious tourists are always advised to gather and travel in group from Tis Abay. As the security guards said, this method can provide additional benefits for tourists, such as, they can help each other through carrying their materials, discuss religious issues and come up with solutions. It is also becomes very easy for managing tourists at the registration and during orientations.

\section{H. Insufficient Space}

Most of the interviewee indicated, during the main annual festivities, it is very difficult and even impossible to handle the entire religious tourists. Most of the religious tourists cannot get a place rest unless reserved well in advance. According to estimation of the culture and tourism office of the district, yearly, around 30,000 religious tourists are accommodated only during the annual festivals of the monastery. However, the carrying capacity of the site cannot handle this much. The severity of the problem is well addressed by of the interviewees in the following ways:

"...well, as it can be seen, the monastery is found in the middle of the rugged mountains area. Look around! It is a hill. The area is very narrow. This makes difficult to accommodate all religious tourists during summer and annual festivals."

As proved through observation and information from informants, to solve the problem during the peak season, the monastery is now constructing big halls to accommodate lots of religious tourists especially during the annual celebration.

During the high season, sanitation is another problem which is noticeable. The influxes of religious tourist during the annual festivities requires place for cleanliness. However, since it is difficult to provide the facility for the crowd, sanitation problems are happing at the destination. However, as the researchers observation proved there is good movement and plans to make the monastery neat, clean and safe religious site. At the moment, Dokmit River is the only alternative to wash cloth, to shower and so on. During summer (Ethiopian rainy season), the service of the reviver no longer becomes available since the level of water increases, it is difficult to use it.

\section{Opportunities for Religious Tourism Development}

\section{A. Availability of other significant attraction sites near by}

Tis Esat fall, on the Blue Nile River locally called Abay, is one of the most famous tourist attraction sites in Ethiopia. It attracts lots of domestic and foreign tourists from different corners of the world. The Blue Nile River is a tributary of the world's longest river, the Nile, which originates in Ethiopia. The monastery is located 5 k.m far from Abay River. The existence of the Blue Nile Camp seen, through the observation of the researchers, as opportunity for future religious tourism development at the monastery.

\section{B. Wide Spread of Academic Institutions in the country}

As observed today in Ethiopia, there are a widespread academic institutions in different directions of the country. There are forty-one universities in Ethiopian and are expanding. This enables many tourism destinations to be explored through academicians and researchers through time. Tourism knowledge is educated on various schools around tourism areas delivering the sector educated personnel for guiding, hotel and restaurant management, tourism business as tour operator, serving and reception activities (Kauffmann, 2008). The spread of academic institution will help in producing skilled professional; which would a good opportunity for the development of religious tourism at the monastery.

\section{Conducive Government Policies and Strategies}

There is a good policy of the government to develop the tourism destinations. In Ethiopia, in 2008 a tourism policy was introduced by the Ministry of Culture and Tourism. The strategy consists of six pillars, a) human resource development, b) infrastructure development, c) image strategy, d) service improvement, e) strengthening information and management capacity, and f) domestic tourism promotion (MoCT, 2008). It reveals that in Ethiopia, there are best opportunities since the tourism policy under Ministry of Culture and Tourism has developed a strategy regarding the domestic tourism promotion.

There are famous and honey pot tourist destinations which are already developed and promoted throughout the world and are found in Amhara region like the Rock Hewn Churches of Lalibela, Semien mountains national park, Gondar Castles, Lake Tana Monasteries, Tis Abay Fall. As depicted through the result 
of FGD and interview, the monastery is located among top five tourism destinations which are getting the future priority from the regional government to be developed.

\section{Technological Advancement}

Information and communication technologies have been fully embraced in the field of pilgrimages and religious tourism. Currently for the development of religious tourism at the monastery, technology can used as the best opportunity. As FGD revealed, today, it is through the use of technology that every religious tourists can get full information and access to the religious tourism site. Because of the development and accessibility of technology, interested body can access full information through the website of the monastery.

As informant explained, the monastery is promoting itself without the help of other stakeholders. It is through religious tourists who are flowing to the site by having full information through the social media. Therefore, understanding and using technology can be an opportunity for religious tourism development in the monastery.

\section{E. The Growing Number of Religious Tourists}

There are 50,000 religious organizations worldwide that organize pilgrimages (Wright, 2007). Religious tourism is becoming internationalized; whereas this kind of tourism was previously a largely domestic phenomenon, it now involves different nationalities. The spectacular development of religious tourism destinations over the past thirty years has allowed pilgrimages to regain the prominence they enjoyed in the past, making it possible for religious gatherings to attract millions of persons (UNWTO, 2007). Observation proved that, in Adyame Yordanos Wonkshet Monastery, the number of religious tourists is growing in a big rate.

The daily number of religious tourists who visited the monastery from 24/01/2018 -07/02/2018 was registered with lowest number 150 on 25/01/2018 and the highest on 20/05/2018 with 250 religious tourists. As per the interview with an informant, during January, the reason for the lowest number was many people want to celebrate Epiphany with their family and also it was wedding occasions for some. The highest number was registered during 14/02/2018 which was more than 600 religious tourists. The average number of religious tourist which was registered daily was 300. Even during the March, the number reached up to 600 religious tourists in a day. However, as per explanations of an interviewee, in the last days of the month the number of tourists decreases due to the need to celebrate the Easter holyday with their family.

As per the illustration of interview, during fasting season, the number of religious tourist becomes very high. This results in the growth of different types of religious tourist which will put its own positive impact on the development of religious tourism in the monastery. The rise in demand for religious travel is clearly part of a larger trend towards deeper interest in religious products (Okonkwo, 2015). This finding is also similar with the finding of Mr. Belay in 2013; on his studying of the religious tourism development at a religious site Gishen Debre Kerbe, in Ethiopia.

\section{F. The Reputation of the Monastery}

As an aggregate response of the interview and FGD showed the monastery is well reputed as a place to receive deliverance and receive a divine cure. Its healing power of the spa (holy water) and the blessing the place has can be a good opportunity to attract many religious tourists in the future.

Most of the monastery informants indicated that, most importantly, those religious tourists who have received a divine cure and deliverance from bad sprite are now promoting the monastery through social media and words of mouth, assisting the financially, providing with infrastructure and facilities, delivering counseling and advising service through difficulties, testifying how they can be benefited and cured from their problem to the public, participating in religious service provision in the monastery.

\section{G. Local Travel Associations}

Travel associations are the best opportunities to diversify and develop tourism products and destinations. Likewise, the monastery has its own legal travel associations in most of the major cities and towns in Ethiopia. It is named as “Adyame Yordanos Wonkshet St. Gabriel Monastery Travel Association”. They are promoting pilgrimage to the monastery. They by register the full address of travelers, arranging transport, and handling problems related to the travel. Some travel associations are now constructing a big hall in the monastery. So during the annual festival the halls can be used to provide accommodation to the pilgrims. The halls can also serve religious tourists all the year round as demanded. Most of the facilitators of the travel 
associations are those who have received the blessing of the site; being cured from different disease and they are providing free service for the religious tourism development.

\section{Conclusion}

This study was conducted to investigate the challenges and opportunities for religious tourism development: the case of Adyame Yordanos Wonkshet Monastery. The study showed that monastery is one of the most famous religious sites. It is proved that the monastery is rich with a variety of natural and cultural resources which are used for religious tourism development.

Though the monastery is endowed with resource potentials, there are challenges. The result of the study indicates that, thefts and robbery, insufficient land for accommodating religious tourists, lack of electricity, parking problem, loss of spirituality with religious tourists due to modernization, unskilled experts, inaccessibility, unity and coordination problem among stake holders as the challenges of religious tourism development.

The result of the study also showed many opportunities which can have a role in the development of religious tourism in the study area. It includes the growing number of religious tourists, technological advancement through promoting the religious resources and practices, those who have been cured from their mental and physical illness, Tis Esat fall and the newly established Blue Nile camp, Government and the local travel associations have been identified.

Generally, the study proved that the monastery is one of the most prominent religious tourism sites in Ethiopia which is developing fast in the terms of religious tourism. But, the aforementioned challenges must be curved and the opportunities harnessed.

\section{Recommendations}

$>$ The monastery and South Gondar diocese leaders should work in collaboration with the tourism experts and other governmental sectors to get training on minimizing challenges different challenges promoting the religious potentials of the monastery.

$>$ For the sake of minimizing the challenges, they should develop the codes of conduct which should be practiced during the stay of religious tourists at the monastery.

$>$ There should be comment book which can be put at the exit of the monastery for getting the updated comments regarding the challenges which are found in the monastery

$>$ As it is the religious site, the monastery leaders should work with the Blue Nile Camp, local and national travel associations and others

$>$ Taking appropriate attentions to set and formulate appropriate codes of conducts in collaboration with the monastery to identify and minimize the challenges such as facility problems.

$>$ At the office, there should be sufficient information regarding the monastery and its religious activities.

$>$ They should solve the land problem, the infrastructure problems in collaboration with other government bodies.

$>$ Provide attention for the use and implementations of opportunities like the tourism strategies, rule and regulations and policies at the religious site.

$>$ There should be an opportunity through the institution for the researchers to give credit and explore religious treasures at the religious site.

$>$ The religious tourists should keep the religious site clean and neat during their stay.

$>$ They should recommend any challenges which can affect the religious tourism development for responsible body like the monastery leaders and tourism experts.

$>$ Religious tourists should understand the codes of conduct of the religious site and apply all them well during their stay.

$>$ They should be aware about the religious tourism travel tools and equipment's before they start to go to the religious site.

$>$ Most of the time during the peak time, there may be problems such as theft/robbery. So religious tourist should be aware of such activities. 
References

Bader, M. (2012). Religious Tourism In Jordan: Current Situation, Future Developments And Prospects ,A Case Study On Islamic And Christian Holy Sites.

Belay, A. (2013). challenge and opportunity of religious tourism at religious site:the case of Gishen Drbe Kerbe.

Destnation. BC,crop. (2014). Tourism Business Essentials: Cultural and Heritage Tourism Develop-ment.

Ermias and Mulugeta (2014). Religious tourism potential of Gishen Derbe Kerbe Mariam, Ethiopia. African Journal of Hospitality, Tourism and Leisure Vol. 3 (1) - (2014)

Farhat R. ,Ummara F.,Sundas S. (2016). Religion Tourism And Entrepreneurial Development (A Case Study Hazrat Data Ganj Bakhsh Shrine), South Asian Studies . A Research Journal Of South Asian Studies Vol. 31, No. 1, 275-289.

Gurung, R. K. (2016). Marketing Religious Tourism Destination. Case Study: The Birthplace Of Gautama Buddha, Lumbini, Nepal.

Hagre media \& SGZCTO. (2015). South Gondar zone tourism contents. hagre media communication private limited company.

Karbo, T. (2013). Religion and social cohesion in Ethiopia, Africa Programme of the University for Peace (UPEACE), Addis Ababa, Ethiopia. .

Kauffmann, A. ((2008). Challenges and Future Perspectives for Tourism Development in The Central Rift Valley, Ethiopia.

Kifle, E. (2014). Challenges of Religious Tourism Development: The Case of Gishen Mariam. Ethiopia American Journal of Tourism Research Vol. 3, No. 2, , $42-57$.

Kinfe Abrha (2015). the Potentilas, Challenges and Opportunties Of the Ethiopia Orthodox tewahdo church for religious tourism development: the case of Aksum Town.

Melese. (2015). contribution and challenges of Ethiopian orthodox tewahido church for sustainable tourism development: in the case of Gondar city, Gondar university, Ethiopia.

Mengistu, G. (2008). Heritage Tourism in Ethiopia, Addis Ababa. Ethiopi.

Nurhssen.S. (2016). The Role Of Tourism On Local Economic Development Of Gondar City, Amhara Regional State, Ethiopia. J Glob Econ 4: 207. Doi: 10.4172/2375-4389.1000207.

O’Gorman, K. D. (2010). The Origins Of Hospitality And Tourism Good Fellows, Oxford .

Okonkwo, E. (2015). "Religious Activities and their Tourism Potential in Sukur Kingdom, Nigeria," . International Journal of Religious Tourism and Pilgrimage: Vol. 3: Iss. 1, Article 3.

Olsen, D. (2006). Management Issues For Religious Heritage Attractions. In Timothy, D., \& Olsen, D. (Eds.). (2006). Tourism, Religion And Spiritual Journeys (Vol. 4). Routledge Organization.

Pintér, A. R. (2014). Religious tourism in Mecca.Saudi Arabia.Budapest Bussiness school .college of commerce, catering and tourism.

Rodriques, A. (2012). Motivations, Experiences and Potential Impacts of Visitors to a Monastery in New Zealand: A Case Study. The University of Waikato.

Rob Matthews and liz Ross . (2010). research method a practical guide for social science, University of Birmingham. Pearson Education Limited. 
Simone-Charteris, M.T \& Boyd, S. (2010). The Development of Religious Heritage Tourism in Northern Ireland: Opportunities, benefits and obstacles.

Stemler, S. (2001). An Overview of Content Analysis. Practical Assessment, Research \& Evaluation.

Tala, M. L. (2014). Dimensions Of Religious Tourism Bucharest Academy Of Economic Studies.

The Federal Democratic Republic of Ethiopia, the Ministry of Culture and Tourism (2008). the Ethiopian Tourism Policy. Addis Ababa.

UNWTO. (2007). International Conference On Tourism And Religions: a Contribution to the Dialogue Among Religions, Cultures and Civilizations. Summary of the Report of Córdoba, 29-31 Octobe.

UNWTO. (2014). Network of Religious Tourism. international conference on tourism and pilgrimage, project brief held in Spain.

World Bank. (2013). Tourism in Africa: Harnessing Tourism for Growth and Improved Livelihoods. Jackson: Appalachian State University.

Wright, K. (2008). Religious Tourism and Pilgrimage Management, 2nd Edition: An International Https://Books.Google.Com.Etaccessed On November 2017. 